\title{
Multi-TeXtualism, 'TREATy HEGEMONY' AND THE WAITANGI \\ TRIBUNAL: MAKING SENSE OF 19TH CENTURY CROWN-MĀORI NEGOTIATIONS IN TE UREWERA
}

\section{Hannah Blumhardt ${ }^{*}$}

\begin{abstract}
Between 1894 and 1896 the Crown conducted negotiations with Tühoe which culminated in the 1895 Urewera Agreement and the Urewera District Native Reserve Act 1896. This article considers the constitutional implications of these negotiations and the resulting agreement and legislation. Adopting a 'multi-textual' conception of New Zealand legal history, and paying heed to the fact that Tühoe did not sign the Treaty of Waitangi, the article argues that the Crown-Tühoe relationship should be grounded predominantly in the 1895-1896 Agreement rather than the Treaty of Waitangi. In making this argument the article critiques the Waitangi Tribunal's approach to these particular points in the first two pre-publications of its Te Urewera Report. The article argues that in finding that the Crown-Tühoe negotiations and agreement signalled the beginning of a relationship based upon the Treaty of Waitangi, the Waitangi Tribunal erred in its approach.
\end{abstract}

\section{INTRODUCTION}

This article considers the constitutional implications of the Crown-Tūhoe negotiations that took place between 1894 and 1896, culminating in the Urewera Agreement 1895 (the Urewera Agreement) and the Urewera District Native Reserve Act 1896 (the UDNRA). The article will consider the historical background to the Urewera Agreement, its singularity in New Zealand's legal history, as well as how it should be considered, in terms of both its content and its constitutional status, particularly in relation to the Treaty of Waitangi. Focus will be placed on critically reviewing

\footnotetext{
* $\quad$ Paper submitted in fulfilment of the requirements of an LLB(Hons) degree. The author wishes to thank Professor Richard Boast for his committed assistance and support as a supervisor, providing invaluable comments and feedback on various drafts of this paper, as well as access to a range of relevant Waitangi Tribunal resources.
} 
the Waitangi Tribunal's first two pre-publications of the Te Urewera report, particularly its discussion of, and approach towards, these particular points.

When considering almost any aspect of Crown-Māori relations, the Treaty of Waitangi is omnipresent, both historically and today. While in many cases this might be appropriate, in the case of iwi who did not sign the Treaty, such as Tūhoe, this approach may be problematic. The case of Tūhoe is especially interesting because not only did its representatives not sign the Treaty, ${ }^{1}$ but its relationship with the Crown was shaped by an entirely different set of negotiations - the Urewera Agreement and the UDNRA. The UDNRA, which partially passed aspects of the Urewera Agreement into law, consolidated a degree of Tūhoe autonomy and self-government that was unique in the New Zealand legal context. ${ }^{2}$ Consequently these arrangements present their own legal and constitutional implications.

It will be argued that the Crown-Tūhoe relationship should be grounded predominantly in the Urewera Agreement rather than the Treaty of Waitangi. This argument builds upon an increasing acknowledgement of the multi-textual nature of New Zealand's legal history and Crown-Māori relationships, which should move New Zealand beyond a myopic focus on the Treaty of Waitangi as the sole document defining Crown-Māori relationships. ${ }^{3}$ In making this claim it will be argued that the particular singularity of the Urewera Agreement, as well as its highly constitutional nature, are grounds for recognising it as central, rather than peripheral, to the Treaty in determining the CrownTūhoe relationship.

It will be argued that the Waitangi Tribunal failed to recognise this when considering the constitutional relationship between the Crown and Tūhoe. The Tribunal did not pay due regard to the twin realities that Tūhoe did not sign the Treaty and that an entirely different agreement underlay their relationship with the Crown; realities which should be treated as interlinked. Furthermore it seems the Tribunal was also reluctant to recognise the Urewera Agreement as central to the Crown-Tūhoe relationship because it felt constrained from doing so by its statutory jurisdiction, and because of a general apprehension towards engaging with New Zealand legal history as a multi-textual domain. Consequently, despite the Tribunal's recognition that the Urewera Agreement was of considerable "constitutional significance", ${ }^{4}$ its reasoning led it to assess the

$1 \quad$ Waitangi Tribunal Te Urewera Pre-Publication Part I (Wai 894, 2009) at 127, 138-139.

2 Chris Finlayson, Minister for Treaty Negotiations "Speech for Launch of Dame Judith Binney's 'Encircled Lands' at Parliament" (Grand Hall, Parliament, Wellington, 18 December 2009); Richard Boast "Recognising Multi-textualism: Rethinking New Zealand's Legal History" (2006) 37 VUWLR 547 at 575; Waitangi Tribunal Te Urewera Pre-Publication Part II (Wai 894, 2010) at 482-483.

3 See Richard Boast "Recognising Multi-textualism: Rethinking New Zealand's Legal History", ibid.

$4 \quad$ Waitangi Tribunal Te Urewera Pre-Publication Part II, above n 2, at 482. 
Urewera Agreement through a Treaty of Waitangi lens. This has the effect of belittling the Urewera Agreement's constitutional weight by subordinating it to the Treaty.

In making these arguments it is first necessary to consider the basic aspects of the Urewera Agreement, its negotiation, and the issues it canvassed.

\section{THE UREWERA AGREEMENT}

\section{A From the Negotiations to the Act}

Outside of the Treaty of Waitangi, the Urewera Agreement and the UDNRA form one of the most significant agreements between any iwi group and the Crown, and "probably the best-known of the three major late 19th century regional negotiations". ${ }^{5}$ Negotiated in depth over a period of months, it is appropriate to take a holistic approach and view the various stages of the Urewera Agreement, culminating in the UDNRA, as a whole. This section provides a background to these various stages and the points discussed and negotiated at each.

The initiation of talks can be traced back to several hui in 1894 between Premier Seddon and various iwi throughout the Urewera region. ${ }^{6}$ Although Edwards argues that there was no "direct line of negotiation between the 1894 tour and what became the 1896 Act", ${ }^{7}$ it is clear that at these hui a relationship was formed, ${ }^{8}$ and many matters which would influence the later Urewera Agreement were discussed. Furthermore it was agreed that negotiations would be undertaken in Wellington to the end of producing an agreement between the Crown and Te Urewera iwi. ${ }^{9}$ In terms of content, "[t]he distinctive issue that emerged in the discussions held in the Rohe Potae was the possibility of self-government". ${ }^{10}$ This was not unlimited however, and it was also established that the iwi of Te Urewera were willing to acknowledge the Queen, that they were not seeking either a second government or separation, and that they merely wanted the authority and autonomy to manage their

5 Richard Boast "Recognising Multi-textualism: Rethinking New Zealand's Legal History", above n 2, at 565.

6 Cathy Marr The Urewera District Native Reserve Act 1896 and Amendments (Wai 894, 2002, Doc No A21) at 31 and 33; Anita Miles Te Urewera (first release of a Working Paper for the Waitangi Tribunal, Rangahaua Whanui District 4, Wellington, 1999) at 255-256 and 283; see generally Judith Binney Encircled Lands: Te Urewera 1820-1921 (Bridget Williams Books, Wellington, 2009) at 345-361; but see Cecilia Edwards Urewera District Native Reserve Act 1896 Part 1: Prior Agreements and the Legislation (Wai 894, 2004, Doc No D7(a)) at 116 who sees the 1894 hui as the beginning of good will between the parties, rather than the initiation of negotiations.

7 Cecilia Edwards Urewera District Native Reserve Act 1896 Part 1: Prior Agreements and the Legislation, ibid.

8 Ibid.

9 Judith Binney Encircled Lands: Te Urewera 1820-1921, above n 6, at 349; Waitangi Tribunal Te Urewera Pre-Publication Part II, above n 2, at 364.

10 Ibid at 345 
own affairs and maintain their lands. ${ }^{11}$ There was also discussion of surveys, determining land titles, and the promise of schools, roads and government protection. ${ }^{12}$

The subsequent negotiations in Wellington occurred in 1895, one on 7 September and one on 23 September. ${ }^{13}$ From the meeting on 7 September all that is left are the minutes of the meeting, not "the precise terms" of what was sought and conceded by the parties. ${ }^{14}$ The record of Seddon's speech indicates that several things were discussed. In particular, that an external boundary to the Urewera region should be defined through a triangulation survey, ${ }^{15}$ that provision should be made for roads to be built through the area and for tourists to be permitted, ${ }^{16}$ that the government would not undertake any subdivisional surveys (something which had already produced considerable hostility between the government and Tūhoe), ${ }^{17}$ but that a system of title investigation was necessary, and that a commissioner should be appointed to determine internal hapu boundaries, ${ }^{18}$ and finally that a selection of hapu or local committee as well as a general or central committee, to manage Tūhoe affairs would be desirable. ${ }^{19}$ Seddon also stipulated that what was covered at the meeting should be given effect through legislation, and that accordingly a Bill would be introduced giving "all power" to Tūhoe, including the power to select committees to manage their affairs within their defined boundary. ${ }^{20}$ The passing of legislation was considered an important point to both sides; as Wi Pere stressed, "... if what we have said today is not lasting and not completed by legislation and completed as agreed then Tūhoe will forget you". ${ }^{21}$

11 Ibid at 357-358; Vincent O'Malley Agents of Autonomy: Maori Committees in the Nineteenth Century (Huia Publishers, Wellington, 2007) at 227.

12 Waitangi Tribunal Te Urewera Pre-Publication Part II, above n 2, at 364.

13 Cecilia Edwards Urewera District Native Reserve Act 1896 Part 1: Prior Agreements and the Legislation, above n 6, at 167 and 188; Judith Binney Encircled Lands: Te Urewera 1820-1921, above n 6, at 383 and 386; Richard Boast "Recognising Multi-textualism: Rethinking New Zealand's Legal History", above n 2, at 567.

14 Cecilia Edwards Urewera District Native Reserve Act 1896 Part 1: Prior Agreements and the Legislation, ibid at 178 .

15 Ibid at 173 and 182.

16 Ibid at 173-174 and 180

17 Ibid at 182.

18 Ibid at 174 and 181.

19 Ibid at 174 and 180.

20 Ibid at 177 and 182.

21 Wi Pere "Urewera Deputation, Notes of Evidence" (7 September 1895) (Archives New Zealand, Wellington, No J1/1897/1389) at 53-55, quoted in Judith Binney Encircled Lands: Te Urewera 1820-1921, above $\mathrm{n} 6$, at 386 . 
The only available records of the meeting held on 23 September are reports in the press. ${ }^{22}$ The meeting seems to have been largely a consolidation of the 7 September meeting, as "the same topics were again traversed". ${ }^{23}$ However following this, in fulfilment of a promise "to make available a written record of what the delegation had requested and his response", ${ }^{24}$ Seddon produced a memorandum on 25 September which attempted to summarise the key points agreed to date. ${ }^{25}$ This included the desire to permanently determine the Rohe Potae of Tūhoe land and the appointment of a commissioner to do so. ${ }^{26}$ It was stipulated that the commissioner should also determine the boundaries of the land belonging to hapu and inquire into the titles of people owning land within the area. ${ }^{27}$ Following this, hapu should elect local committees to manage hapu affairs while a general committee should be formed to deal with tribal lands more generally. ${ }^{28}$ Clearly the recognition of Tūhoe self-government continued to be a key part of the points decided to date. Nevertheless, Seddon's memorandum also stated to the iwi of the Urewera: "you acknowledge that the Queen's 'mana' is over all, and that you will honour and obey Her laws". ${ }^{29}$ Cecilia Edwards argues that this statement demonstrates "Seddon's understanding that Tūhoe accepted the Queen as sovereign". 30 However, Seddon then himself acknowledged that, were Tūhoe to maintain a degree of autonomy, this would not contradict or undermine their acceptance of the Queen's sovereignty, a concession which Binney notes was a "significant legal advance". ${ }^{31}$

22 Cecilia Edwards Urewera District Native Reserve Act 1896 Part 1: Prior Agreements and the Legislation, above $\mathrm{n}$, at 188 .

23 Judith Binney Encircled Lands: Te Urewera 1820-1921, above n 6, at 386.

24 Cecilia Edwards Urewera District Native Reserve Act 1896 Part 1: Prior Agreements and the Legislation, above $\mathrm{n}$ 6, at 191 .

25 Richard Boast "Recognising Multi-textualism: Rethinking New Zealand's Legal History", above n 2, at 567; Judith Binney Encircled Lands: Te Urewera 1820-1921, above n 6, at 386; Cecilia Edwards Urewera District Native Reserve Act 1896 Part 1: Prior Agreements and the Legislation, above n 6, at 191.

26 Cecilia Edwards Urewera District Native Reserve Act 1896 Part 1: Prior Agreements and the Legislation, ibid at 191.

27 Ibid at 191-192.

28 Ibid at 192.

29 Judith Binney Encircled Lands: Te Urewera 1820-1921, above n 6, at 388.

30 Cecilia Edwards Urewera District Native Reserve Act 1896 Part 1: Prior Agreements and the Legislation, above $\mathrm{n}$ 6, at 191.

31 Judith Binney Encircled Lands: Te Urewera 1820-1921, above n 6, at 388. 
The memorandum also stated that an Act would be passed "giving effect to what is here set forth". ${ }^{32}$ The Urewera District Native Reserve Bill was shortly thereafter introduced by Seddon in October 1985, accompanied by a statement that "he was introducing it in fulfilment of the commitment he had made to the delegation." ${ }^{33}$ The Tūhoe delegation had an opportunity to comment on and change the draft Bill in $1895 .{ }^{34}$ Following this, a new Bill was introduced by the Hon James Carroll in 1896. ${ }^{35}$ As the Bill passed through the various stages of the legislative process changes were made, some with Tūhoe's consent and some without. Although the changes made by the Native Affairs Select Committee "reflected in part the wishes of the delegation", ${ }^{36}$ not all of them did. For example, the addition of a section which stated that land could be leased or sold only to the Crown (albeit with the authority of the General Committee), ${ }^{37}$ "was not what Tūhoe had wanted"; 38 they had wanted an inalienable reserve with the retention of a capacity to lease land to individuals and families. ${ }^{39}$ Furthermore, as Binney notes, "some last-minute alterations were made by the government without consultation". ${ }^{40}$

In 1896 the UDNRA was passed. Binney highlights that the UDNRA was intended to enact the agreement, "to accord with the views of the Urewera people, and to provide the means for their internal self-government". ${ }^{41}$ This certainly seems to accord with the legislation's preamble. ${ }^{42}$ However in reality this intention was undermined, given that the practical means for ensuring such self-government were not adequately defined and the government was left with much discretion and regulatory power in this regard. ${ }^{43}$ Nevertheless, the UDNRA included the establishment of the

32 Memorandum from RJ Seddon (Premier and Minister of Native Affairs) to Tūhoe Representatives of Urewera Delegation regarding points agreed to date between the parties (25 September 1895) as noted in Urewera District Native Reserve Act 1896, sch 2.

33 Judith Binney Encircled Lands: Te Urewera 1820-1921, above n 6, at 389.

34 Ibid at 392; Cecilia Edwards Urewera District Native Reserve Act 1896 Part 1: Prior Agreements and the Legislation, above n 6, at 202 and 298; Waitangi Tribunal Te Urewera Pre-Publication Part II, above n 2, at 366.

35 Cecilia Edwards Urewera District Native Reserve Act 1896 Part 1: Prior Agreements and the Legislation, ibid at 206.

36 Ibid at 208.

37 Waitangi Tribunal Te Urewera Pre-Publication Part II, above n 2, at 438.

38 Judith Binney Encircled Lands: Te Urewera 1820-1921, above n 6, at 401 (emphasis in original).

39 Ibid at 399-401.

40 Ibid at 392.

41 Ibid at 398.

42 Urewera District Native Reserve Act 1896, Preamble.

43 Judith Binney Encircled Lands: Te Urewera 1820-1921, above n 6, at 398 and 404; Cecilia Edwards Urewera District Native Reserve Act 1896 Part 1: Prior Agreements and the Legislation, above n 6, at 254; 
Urewera Commission, made up of seven Commissioners (five Tūhoe and two European), who would be in charge of dealing with land. ${ }^{44}$ Furthermore the Native Land Court was excluded from operating within the area, although as both Boast and the Waitangi Tribunal note, the UDNRA was still geared towards producing the individualisation of title. ${ }^{45}$

Binney concludes that the UDNRA presented "a mixed bag of blessings" for Tūhoe, ${ }^{46}$ while Boast calls it "an odd mixture". ${ }^{47}$ It legally authenticated the possibility of local self-government in Te Urewera, but simultaneously "brought the Urewera under the Crown's overarching authority" by consolidating Tūhoe's acknowledgement of the Queen's mana. ${ }^{48}$ Furthermore the individualisation of title went against Tūhoe's wishes as expressed in Seddon's memorandum, specifically that in determining title, "due consideration to Native manners and customs" should be made, ${ }^{49}$ and that title would be determined at the level of the hapu. ${ }^{50}$ As noted above, the provision allowing for the alienation of land, and only to the Queen, also contradicted the Urewera delegation's wishes.

\section{B Determining the 'Agreement' and the Points Agreed}

Whether the 1895 preparations for the UDNRA can of themselves be considered an agreement is contestable. Cecilia Edwards argues that "the precise details ... were yet to be worked out" and that "[t]here was no formal document signed by both parties setting out the respective items yielded in return for anticipated rewards". ${ }^{51}$ Binney, however, takes the contrary approach, referring to "the agreement of 1895", 52 and noting that the published account of the 7 September meeting stated that

Waitangi Tribunal Te Urewera Pre-Publication Part II, above n 2, at 453-454; Anita Miles Te Urewera, above n 6, at 284; Danny Keenan "Autonomy as Fiction: The Urewera Native District Reserve Act 1896" in Danny Keenan (ed) Terror in Our Midst: Searching for Terror in Aotearoa New Zealand (Huia Publishers, Wellington, 2008) 79 at 91. For a fuller discussion of the relationship between Tūhoe self-government, Te Mana Motuhake o Tūhoe and the Urewera District Native Reserve Act see Te Rangimārie Williams "Te mana motuhake o Tūhoe" (LLM Thesis, Victoria University of Wellington, 2011).

44 Judith Binney Encircled Lands: Te Urewera 1820-1921, ibid at 398-399.

45 Richard Boast The Crown and Te Urewera in the 20th Century: A Study of Government Policy (Wai 894, 2002, Doc No A109) at 36-37; Waitangi Tribunal Te Urewera Pre-Publication Part II, above n 2, at 434435

46 Judith Binney Encircled Lands: Te Urewera 1820-1921, above n 6, at 404.

47 Richard Boast The Crown and Te Urewera in the 20th Century: A Study of Government Policy, above n 45, at 36 .

48 Judith Binney Encircled Lands: Te Urewera 1820-1921, above n 6, at 404.

49 Memorandum from RJ Seddon, above $n 32$.

50 Cecilia Edwards Urewera District Native Reserve Act 1896 Part 1: Prior Agreements and the Legislation, above $\mathrm{n} 6$, at 196 .

51 Ibid.

52 Judith Binney Encircled Lands: Te Urewera 1820-1921, above n 6, at 388. 
the meeting was to "ratify the agreement" between Carroll and the Urewera delegation. ${ }^{53}$ Presumably the ratification was to come about through engagement with Seddon, who Edwards notes held the "power of consent". ${ }^{54}$ Consequently Seddon's memorandum of the 25 September carries particular weight. At the very least, as Edwards notes, the memorandum "has become a permanent record of Seddon's understanding of what he had agreed with the Urewera chiefs". ${ }^{55}$ However Binney argues further, that it is "akin to a treaty". ${ }^{56}$

Supporting the existence of an agreement is the Tribunal's finding that "[b]y the time the Act was passed, there was genuine agreement on the fundamentals of the new relationship between the Government and Te Urewera". ${ }^{57}$ Even before this, during the second reading of the Urewera District Native Reserve Bill, the Hon James Carroll stated that the Bill was a means of implementing "the agreement between the Government and the Natives in a practical way", ${ }^{58} \mathrm{a}$ statement which indicates that the Government saw what had transpired as an agreement to be kept. Prior to this, in 1986, before the introduction of the second Bill, the Governor Lord Glasgow visited Te Urewera, a visit which a contemporary newspaper report labeled as "confirmatory of the agreement entered into at Wellington". 59

Despite this, the Urewera Agreement's precise moment of formation is elusive. Complicating matters further, the Tribunal notes that during their hearings there was disagreement between the parties as to what had been agreed. ${ }^{60}$ Despite this, the Tribunal found that both parties agreed that dialogue between the Crown and Te Urewera leaders had concluded with Seddon's memorandum, and that this memorandum could be seen as a "heads of agreement". ${ }^{61}$ Thus the Waitangi Tribunal refers to this as "one of the most critical documents in our inquiry". ${ }^{62}$ But it also notes: ${ }^{63}$

53 At 383

54 Cecilia Edwards Urewera District Native Reserve Act 1896 Part 1: Prior Agreements and the Legislation, above $\mathrm{n} 6$, at 197.

55 Ibid at 254 .

56 Ibid at 199 (paraphrasing Binney).

57 Waitangi Tribunal Te Urewera Pre-Publication Part II, above n 2, at 361-362.

58 (24 September 1896) 96 NZPD 157 cited in Cecilia Edwards Urewera District Native Reserve Act 1896 Part 1: Prior Agreements and the Legislation, above n 6, at 196.

59 New Zealand Herald (New Zealand, 27 February 1896) cited in Cecilia Edwards Urewera District Native Reserve Act 1896 Part 1: Prior Agreements and the Legislation, above n 6, at 202.

60 Waitangi Tribunal Te Urewera Pre-Publication Part II, above n 2, at 363.

61 Ibid at 367.

62 Ibid at 426

63 Ibid at 411-412. 
... the documentation and results of the 7 September meeting, the 23 September meeting, and the 25

September memorandum must all be taken together as constituting the agreement reached between the leaders of Te Urewera and the Crown. The agreement cannot ... be confined to the contents of the 25

September memorandum.

Indeed, taking a more expansive view of the Urewera Agreement "agreement" without limiting analysis to one tangible document is probably most helpful and appropriate in this case, particularly given the many meetings and the fact that many of the records from these have been lost. ${ }^{64}$ Furthermore, focusing on Seddon's memorandum would be problematic as it was only his perception of what had been agreed and is therefore potentially one-sided. ${ }^{65}$

Having adopted this holistic approach to the temporal aspect of the Urewera Agreement, the Tribunal took a principle-based approach to determining its content. The Tribunal extracted seven core principles which they believed had been agreed to in September 1895. The seven principles identified were: the establishment of an inalienable reserve; the exclusion of the Native Land Court from the reserve; the awarding of land titles at the hapu level; the provision of a degree of local, self-government to the peoples of Te Urewera; Te Urewera iwi's acknowledgement of the Queen, the government and the law; the government's protection of the peoples of Te Urewera and promotion of their welfare; and the creation of roads, tourism, farming and potential mining within the reserve. ${ }^{66}$ This principle-based approach certainly seems the most practical and sensible way of analysing a situation such as this, where discussions from several occasions are being considered simultaneously. It also reflects the approach used to interpret the Treaty of Waitangi, where focus on the precise terms itself has been recognised as problematic. ${ }^{67}$

But what of the UDNRA? Although the UDNRA could be interpreted as a consolidation of the Urewera Agreement, this is made uncertain by the fact that differences exist between the Urewera Agreement and the UDNRA. ${ }^{68}$ Despite this, in many respects the UDNRA's main flaw was that it was simply so broadly put that it had the potential, in practice, to be a tool by which the spirit of the Urewera Agreement could be undermined (which it later was). Indeed as the Tribunal notes, the Crown and claimants broadly agreed that the UDNRA "captured" the Urewera Agreement's principles, ${ }^{69}$ and that "Treaty breaches arose from the Crown's failure to carry out the [UDNRA],

64 Ibid at 425.

65 Ibid at 365, 411 and 428 .

66 Ibid at 411-412.

67 See New Zealand Māori Council v Attorney-General [1987] 1 NZLR 641 (CA).

68 Richard Boast The Crown and Te Urewera in the 20th Century: A Study of Government Policy, above n 45 , at 40; Cecilia Edwards Urewera District Native Reserve Act 1896 Part 1: Prior Agreements and the Legislation, above n 6, at 239.

69 Waitangi Tribunal Te Urewera Pre-Publication Part II, above n 2, at 433. 
rather than from fatal flaws within the [UDNRA] itself". ${ }^{70}$ This is why the UDNRA must be read in conjunction with the Urewera Agreement that led to it, in order to assist in the interpretation of its broadly phrased sections. The promises that preceded the UDNRA indicate how such sections should have been interpreted and implemented. While reading the UDNRA in a vacuum might lead one to interpret it in a variety of ways, reading it in conjunction with the preceding discussions significantly limits the ways in which the UDNRA may be interpreted.

A further point of relevance is the status of the Urewera Agreement, given that the UDNRA was passed to give effect to it, but was then later repealed. Does the repeal of the UDNRA undermine the case that the Urewera Agreement could still be applicable today? It is submitted that this argument is not tenable and as Boast notes, in the case of all confiscation and regional agreements between the Crown and Māori that were implemented by statutes, the repealing of the statutes has "not had the effect of terminating the agreements". ${ }^{71}$ Indeed the UDNRA was always framed as a means of practically implementing the Urewera Agreement that had already been made (as noted above). ${ }^{72}$ Thus, regardless of the UDNRA, the Urewera Agreement and its seven core principles should be seen to have an independent status, charting the contours of a relationship that the Crown and Te Urewera had forged. The passing of the UDNRA by Parliament was a formality which goes towards indicating the seriousness with which the Government perceived the Urewera Agreement itself, but its repeal cannot detract from the existence of the Urewera Agreement between the Crown (as distinct from Parliament) and Te Urewera.

Having acknowledged both the Urewera Agreement's existence and basic principles, the question becomes, should this agreement be accorded constitutional weight and if so, how? Furthermore, where does it stand in relation to the Treaty of Waitangi, and how were these questions approached by the Waitangi Tribunal? To answer these questions it is necessary to first consider the case for understanding New Zealand's legal history as multi-textual.

\section{THE UREWERA AGREEMENT IN NEW ZEALAND'S MULTI- TEXTUAL CONSTITUTIONAL LANDSCAPE}

\section{A The Tension between Multi-textualism and 'Treaty Hegemony'}

The discourse surrounding Crown-Māori relationships in New Zealand has traditionally been dominated by Treaty of Waitangi hegemony: a reification of the Treaty of Waitangi which has overshadowed due consideration or even acknowledgement of other agreements of potential constitutional importance between the Crown and various iwi. Thus it is frequently presumed that

70 Ibid at 373.

71 Richard Boast "Recognising Multi-textualism: Rethinking New Zealand's Legal History", above n 2, at 572.

72 See (24 September 1896) 96 NZPD 157 cited in Cecilia Edwards Urewera District Native Reserve Act 1896 Part 1: Prior Agreements and the Legislation, above n 6, at 196. 
New Zealand's constitutional landscape is "uni-textual", ${ }^{73}$ and that Crown-Māori relations are to be "balanced on the fulcrum of $1840 "{ }^{74}$

This single-minded focus on the Treaty of Waitangi as the yardstick for measuring the duties of both the Crown and Māori has also impressed itself upon the Treaty settlement process, where the Treaty is the guiding document upon which the Waitangi Tribunal acquires its jurisdiction and upon which settlement claims and Tribunal recommendations are made. ${ }^{75}$ Specifically, s 6 of the Treaty of Waitangi Act 1975 stipulates that the Tribunal's jurisdiction is to assess whether Crown actions were "inconsistent with the principles of the Treaty". ${ }^{76}$ Thus as Byrnes notes, "some observers come close to suggesting that there is one Treaty, and the Tribunal its prophet". ${ }^{77}$ With this fixation on the Treaty, matters of seeming constitutional importance, such as "whether the group seeking redress ever, as a matter of historical reality, actually signed the Treaty" are "not perceived as relevant or even interesting". ${ }^{78}$ This situation is self-reinforcing, as Māori have traditionally "tended to rely on the terms of the Treaty of Waitangi in promoting their grievances" but this, in turn, has "tended to undermine other, no less significant, though now largely forgotten, undertakings made by the Crown at a local level". ${ }^{79}$

As many authors are increasingly noting, this myopic focus on the Treaty of Waitangi as the defining constitutional agreement between Māori and the Crown is not completely justified by historical reality. ${ }^{80}$ Belich notes, it is somewhat of an "artificial watershed". ${ }^{81}$ In particular, Boast

73 Richard Boast "Recognising Multi-textualism: Rethinking New Zealand's Legal History", above n 2, at 553.

74 James Belich Making Peoples: A History of the New Zealanders from Polynesian Settlement to the End of the Nineteenth Century (Penguin, North Shore, 2007) at 115.

75 Richard Boast "Recognising Multi-textualism: Rethinking New Zealand's Legal History", above n 2, at 574; Giselle Byrnes The Waitangi Tribunal and New Zealand History (Oxford University Press, Auckland, 2004) at 8; FM Brookfield Waitangi and Indigenous Rights: Revolution, Law and Legitimation (Auckland University Press, Auckland, 2006), at 106.

76 Treaty of Waitangi Act 1975, s 6.

77 Giselle Byrnes The Waitangi Tribunal and New Zealand History, above n 75, at 16.

78 Richard Boast "Recognising Multi-textualism: Rethinking New Zealand's Legal History", above n 2, at 548.

79 Vincent O'Malley "Treaty-Making in Early Colonial New Zealand" (1999) 33 NZJH 137 at 140.

80 See generally, Vincent O'Malley "Treaty-Making in Early Colonial New Zealand", ibid; Richard Boast "Recognising Multi-textualism: Rethinking New Zealand's Legal History", above n 2; FM Brookfield Waitangi and Indigenous Rights: Revolution, Law and Legitimation, above n 75, at 105-106; James Belich Making Peoples: A History of the New Zealanders from Polynesian Settlement to the End of the Nineteenth Century, above n 74.

81 James Belich Making Peoples: A History of the New Zealanders from Polynesian Settlement to the End of the Nineteenth Century, ibid at 116. 
makes the case "for reinterpreting New Zealand legal history" 82 to better acknowledge its multitextual nature as well as that of the Crown-Māori relationship. ${ }^{83}$ Rather than the Treaty alone, Boast highlights how "the Government of New Zealand entered into hundreds of elaborate, written agreements with Māori after the Treaty of Waitangi". ${ }^{84}$ These many agreements were made with various iwi, some of whom had also signed the Treaty of Waitangi and some of whom had not. ${ }^{85}$ Such agreements included numerous land deals, which Belich has described as "a hundred little treaties", ${ }^{86}$ as well as deeds of cession, confiscation agreements and regional pre-emptive agreements. ${ }^{87}$ Unfortunately these agreements have mostly been either ignored or sidelined as mere "historical curiosities". ${ }^{88}$

While the failure to acknowledge at least some of the agreements in the constitutional landscape alongside the Treaty is a problematic oversight, if we were to acknowledge them, how would we charter such a multi-textual constitutional arrangement? In particular where would such agreements stand in relation to the Treaty of Waitangi? Would they be subordinate or would they override it in their local context? Furthermore, in cases such as Tūhoe, who are non-signatories to the Treaty, is the Treaty relevant to that relationship at all? These are questions that this article seeks to answer through a close analysis of the Urewera Agreement.

\section{B The Urewera Agreement in a Multi-textual Context - a Case for its Singularity}

The last Maori community in the country to retain a high degree of autonomy over its own affairs was to

become the first to gain some measure of legal recognition of its right to administer its own lands. ${ }^{89}$

While it is important to emphasise the multi-textual nature of the Crown-Māori relationship, it is probably unrealistic to argue that the different agreements could all be treated with the same constitutional gravitas. The sheer number of agreements would make this overly burdensome; a case would have to be made about each particular agreement as to whether it amounted to an agreement with real constitutional implications. Although determining the threshold for this could be

82 Richard Boast "Recognising Multi-textualism: Rethinking New Zealand's Legal History", above n 2, at 547.

83 Ibid at 553

84 Ibid at 570 .

85 Ibid at 548.

86 James Belich "Hobson’s Choice" (1990) 24 NZJH 200 at 205 cited in Vincent O'Malley "Treaty-Making in Early Colonial New Zealand", above n 79, at 137.

87 Richard Boast "Recognising Multi-textualism: Rethinking New Zealand's Legal History", above n 2, at 554-560.

88 Ibid at 553.

89 Vincent O'Malley Agents of Autonomy: Maori Committees in the Nineteenth Century, above n 11, at 216. 
contentious, it would probably vary according to the nature of the agreements themselves. As Boast notes, there are hundreds of agreements based on land purchases which probably have less constitutional significance when compared to the regional agreements, such as those with the King Country, and Te Arawa iwi, and that with the Urewera iwi under consideration in this article. ${ }^{90}$ Unlike the deeds of purchase, these regional agreements were undertaken after lengthy processes of negotiation, they included "the close involvement of the national government", covered agreements relating to matters beyond land and "contained respective promises between the parties relating to their relationships in the future". ${ }^{91}$ This article argues that there is a strong case for acknowledging the Urewera Agreement's singularity, as well as its constitutional significance. In particular, when considering the Crown's relationship with Te Urewera iwi specifically, the Urewera Agreement could be seen to carry more weight than the Treaty of Waitangi.

The Urewera Agreement's singularity rests on both the nature of the agreement itself, as well as its historical specificity. It could be argued that, given the multitude of agreements signed between the Crown and various iwi across New Zealand, there is nothing unique about the Urewera Agreement; it was just one of many. However making this argument would not be treating like with like. As outlined above, the Urewera Agreement stands out as one of the three regional agreements, setting it apart from the many land purchase deeds and other agreements of a lesser constitutional nature.

A second factor that sets the Urewera Agreement apart from others is the fact that Tūhoe never signed the Treaty of Waitangi nor did they have input into the negotiations or formulation of it. ${ }^{92}$ It therefore makes little sense to impose this relationship upon Tūhoe when an alternative is available. Brookfield notes that the fact the Treaty has become "a constitutional standard, against which the conduct of the Crown towards Maori and the Maori claims to rights against the Crown are to be assessed", does not mean that this is a situation that is always justified by actual legal and historical reality. ${ }^{93}$ He notes that this is particularly the case when dealing with iwi who did not sign the Treaty. As he argues, "there was no majority rule, either in law or morals, which in any way bound the non-signatories and their hapu". ${ }^{94}$ He then goes on to criticise the Waitangi Tribunal's approach in a 1998 report which stated that "[t]he Treaty of Waitangi was signed by rangatira of hapu, on behalf of all Maori people, collectively and individually". ${ }^{95}$ Brookfield argues that this cannot

90 Richard Boast "Recognising Multi-textualism: Rethinking New Zealand's Legal History", above n 2, at 570.

91 Ibid.

92 Waitangi Tribunal Te Urewera Pre-Publication Part I, above n 1, at 127 and 138-139.

93 FM Brookfield Waitangi and Indigenous Rights: Revolution, Law and Legitimation, above n 75, at 105.

94 Ibid.

95 Waitangi Tribunal Te Whanau o Waipareira Report (Wai 414, 1998) in FM Brookfield Waitangi and Indigenous Rights: Revolution, Law and Legitimation, above n 75, at 105-106. 
possibly be an accurate statement of what occurred in $1840 .{ }^{96}$ Bearing this in mind, in a situation where another agreement was signed which could be of greater relevance to the iwi in question than the Treaty, surely that agreement's importance is bolstered.

Thirdly, Te Urewera had a strong history of autonomy from the Crown well after the Treaty of Waitangi was signed, which seems to underline the constitutional relevance of that document to the iwi of Te Urewera specifically. Until the mid-1860s Te Urewera "remained fully independent of any Crown authority", ${ }^{97}$ while British sovereignty was merely "a legal fiction". ${ }^{98}$ Following the 1871 compact with Donald McLean, Te Urewera iwi were able to continue protecting their mana motuhake. ${ }^{99}$ Binney argues that even until the 1890s Tūhoe were in a state of "de facto" autonomy; ${ }^{100}$ the Crown and the Queen's writ held little sway in the region and attempts to survey the area or even enter it were frequently thwarted. ${ }^{101}$ Premier Seddon himself, when introducing the Urewera District Native Reserve Bill to the House, "recognised an existing state of self-government in Te Urewera" 102 when he stated that the area was already "practically a reserve". ${ }^{103}$ Of particular importance was his statement that as a result, "exceptional circumstances in connection to Tūhoe" existed, which justified the Bill's legal validation of Tūhoe's self-government. ${ }^{104}$

Apparently then, the signing of the Treaty of Waitangi had done little to alter the day-to-day autonomy of the Urewera region, indeed it was insufficient in this regard. The Crown was motivated to find another means of increasing its power in the region. ${ }^{105}$ In short, another agreement was seen to be necessary in order to define the Crown-Tūhoe relationship on terms different to those already in existence pre-1840, given that following October 1840 "life continued unaltered in Te Urewera". ${ }^{106}$ This agreement was undoubtedly then, to have significant constitutional implications

96 FM Brookfield Waitangi and Indigenous Rights: Revolution, Law and Legitimation, ibid at 106.

97 Waitangi Tribunal Te Urewera Pre-Publication Part I, above n 1, at 128.

98 Vincent O'Malley Agents of Autonomy: Maori Committees in the Nineteenth Century, above n 11, at 217.

99 Waitangi Tribunal Te Urewera Pre-Publication Part II, above n 2, at 377.

100 Judith Binney Encircled Lands: Te Urewera 1820-1921, above n 6, at 322, 326, 358, 394 and 404.

101 Ibid at 382; Richard Boast "Recognising Multi-textualism: Rethinking New Zealand's Legal History", above $\mathrm{n} 2$, at $565-566$.

102 Waitangi Tribunal Te Urewera Pre-Publication Part II, above n 2, at 458.

103 (24 September 1896) 96 NZPD 167 in Waitangi Tribunal Te Urewera Pre-Publication Part II, above n 2 , at 457 .

104 Ibid.

105 Danny Keenan "Autonomy as Fiction: The Urewera Native District Reserve Act 1896", above n 43, at 91; Vincent O'Malley Agents of Autonomy: Maori Committees in the Nineteenth Century, above n 11, at 224; Anita Miles Te Urewera, above n 6, at 283.

106 Waitangi Tribunal Te Urewera Pre-Publication Part I, above n 1, at 132. 
and in practice was to be of greater importance than the Treaty of Waitangi for defining the Crown's relationship with Tūhoe.

Fourthly, while Tūhoe had no input or opportunity to negotiate the Treaty, they entered a lengthy and protracted period of negotiations leading up to the UDNRA, in which they were highly involved and invested a great deal of time and energy. This indicates the importance of these negotiations and the agreement that resulted. Indeed, as previously noted, there are grounds to consider it as amounting to a treaty in and of itself. ${ }^{107}$ Certainly both parties considered themselves to be bound by it, ${ }^{108}$ and as the Tribunal notes, Te Urewera iwi were entitled to trust the repeated assurances made to them by the Ministers of the Crown during the negotiation process. ${ }^{109}$ This adds weight to claims of the Urewera Agreement's constitutional significance which, as the Tribunal claimants argued, could be seen to have been further "enhanced when it was ratified and enacted by Parliament". 110

Finally, the significance of the Urewera Agreement is bolstered by the fact that its actual content (not only the circumstances surrounding it) was unusual. As Boast notes, the Urewera Agreement "certainly does embody commitments which the Crown did not extend to other Maori". ${ }^{111}$ The Waitangi Tribunal highlighted it as a "constitutional first" for Māori and New Zealand. ${ }^{112}$ It also stated that "[this] Tribunal has seldom seen an agreement more promising in Treaty terms". ${ }^{113}$ Furthermore the current Minister of Treaty Negotiations, the Hon Christopher Finlayson, also stressed, at the launching of Dame Judith Binney's book Encircled Lands: Te Urewera 1820-1921, the "unique Urewera District Native Reserve Act", saying: ${ }^{114}$

... my understanding of Ngai Tūhoe is that Te Urewera is unique ... The legislation Seddon negotiated was unique. There was nothing else like it in New Zealand. This is not a special situation; nor, indeed, is it an exceptional situation. This is a unique situation.

107 Judith Binney Encircled Lands: Te Urewera 1820-1921, above n 6, at 393; Vincent O'Malley "TreatyMaking in Early Colonial New Zealand", above n 79, at 151.

108 Judith Binney Encircled Lands: Te Urewera 1820-1921, ibid at 393; Richard Boast "Recognising Multitextualism: Rethinking New Zealand's Legal History", above n 2, at 572; Waitangi Tribunal Te Urewera Pre-Publication Part II, above n 2, at 474.

109 Waitangi Tribunal Te Urewera Pre-Publication Part II, ibid at 390, 435, 465 and 474.

110 Ibid at 467.

111 Richard Boast "Recognising Multi-textualism: Rethinking New Zealand's Legal History", above n 2, at 575.

112 Waitangi Tribunal Te Urewera Pre-Publication Part II, above n 2, at 483.

113 Ibid at 474 .

114 Christopher Finlayson, Minister for Treaty Negotiations, above n 2. 
While perhaps the Minister overstates the matter, ultimately it should not be overlooked that the Māori community of Te Urewera was "the first to gain some measure of legal recognition of its right to administer its own lands". 115

Having argued that grounds exist for characterising the Urewera Agreement as one of considerable constitutional importance, the article turns to consider the Waitangi Tribunal's approach to the matter.

\section{THE WAITANGI TRIBUNAL'S APPROACH IN THE TE UREWERA REPORT}

The pre-publication of the Waitangi Tribunal's Te Urewera report considers the UDNRA and the agreements leading up to it. Its approach is of interest and it should be noted from the outset that the Tribunal did not ignore the Urewera Agreement and the UDNRA as a 'historical curiosity'. Rather, the Tribunal demonstrated a real attempt to attribute significance and practical meaning to the Urewera Agreement. It unequivocally rejected the Crown's argument "that nothing unusual was happening here in constitutional terms". ${ }^{116}$ It acknowledged that the Urewera Agreement and the UDNRA presented a "constitutional first", ${ }^{117}$ that it was of considerable "constitutional significance", 118 and that this was: ${ }^{119}$

... the first time the colonial State had recognised a Maori district in this way: to be set aside entirely as

a reserve for its people, and to be governed by them through a legally empowered local authority.

Nevertheless, there are several difficulties in the Tribunal's logic and reasoning.

The crux of the Tribunal's reasoning was to claim that the Urewera Agreement and the enacting of the UDNRA brought the two parties together into a relationship based on the Treaty of Waitangi. Whereas prior to this agreement the Treaty relationship was seen by the Tribunal to be unilateral (in that only the Crown owed obligations under it to Tūhoe), ${ }^{120}$ following the agreement both sides were considered to be in a Treaty relationship. Thus the Tribunal states: ${ }^{121}$

115 Vincent O'Malley Agents of Autonomy: Maori Committees in the Nineteenth Century, above n 11, at 216.

116 Waitangi Tribunal Te Urewera Pre-Publication Part II, above n 2, at 482.

117 Ibid at 483 .

118 Ibid at 482.

119 Ibid at 482-483.

120 Ibid at 466.

121 Ibid at 484. 
... we have concluded that a fully consensual relationship under the Treaty of Waitangi was established by the negotiations of 1894 to 1895, the agreement of September 1895, and the consequential honouring of that agreement in the enactment of the Urewera District Native Reserve Act.

It seems that, to the Tribunal, the making of the Urewera Agreement effectively constituted Tūhoe's fulfilling of its part of the 'signing' of the Treaty of Waitangi which up until that point was apparently still pending. By making this finding the Tribunal was able to pinpoint the moment in which the Treaty relationship between Tūhoe and the Crown began.

This approach therefore seems to reconcile the fact that Tūhoe never signed the Treaty of Waitangi, with the legal reality that in the present day it is nevertheless seen to be bound by its terms. It also seems to demonstrate the Tribunal's own understanding of the relationship between the Urewera Agreement and the Treaty: the Urewera Agreement is subordinate to the Treaty of Waitangi, in that its signing was a means of entering into the Treaty relationship, rather than a means of initiating a relationship based on a different agreement in and of itself. Thus any failure to adhere to the Urewera Agreement would be a grievance Tūhoe could pursue by virtue of its being a breach of Treaty obligations. ${ }^{122}$

At first blush this approach seems ingenious, particularly given that it avoids awkward issues relating to the Tribunal's statutory jurisdiction. It allows the Tribunal to justify its consideration of whether the Crown upheld its part of the Urewera Agreement, and to justify measuring Crown actions against the terms of the Urewera Agreement, while not explicitly diverging from its jurisdiction to consider events through the lens of breaches of the Treaty of Waitangi. It also accords with the Tribunal's decision that the Crown at that point already owed unilateral Treaty obligations to Tūhoe, therefore it is at least logical that the Crown's obligations to uphold the Urewera Agreement were maintained given that, presumably, "the various principles of the Treaty that have been developed by the Tribunal embody the concept that later, particular pacts ought to be kept". ${ }^{123}$

However, the problem with the Tribunal's particular approach is that it seems to go too far. If the Crown owed unilateral obligations towards Tūhoe under the Treaty anyway, this would be sufficient ground to justify assessing the Crown's adherence to the Urewera Agreement; it is not apparent why it was also necessary to place Treaty obligations on Tühoe. And if this was necessary, the Tribunal does not adequately address why this is the case, or even how it could be justified on a legal basis. There seems to be no basis for rejecting the claimants' argument that "the Treaty of Waitangi has remained a unilateral set of promises made by the Crown. The result ... is that Tūhoe do not owe Treaty-based obligations to the Crown". ${ }^{124}$

122 Ibid at 465-485.

123 Richard Boast "Recognising Multi-textualism: Rethinking New Zealand's Legal History", above n 2, at 575.

124 Waitangi Tribunal Te Urewera Pre-Publication Part I, above n 1, at 129. 
Specifically, how is it that the entering into one agreement triggers the application of an entirely separate agreement which one party was never involved with nor consented to? Although it is true that during negotiations reference was made to the Treaty of Waitangi and to Tūhoe's concession to recognising the Queen's law, it is difficult to conclude that this was sufficient to constitute a virtual or indirect signing of the Treaty of Waitangi itself and may instead indicate that the iwi were willing to forge an agreement with a similar spirit and intent. And in any case this was not argued by the Tribunal. Rather, the Tribunal seems to indicate that the act of the Crown acting consistently with its Treaty obligations by going through the negotiation process, and then enacting this in the UDNRA, constituted the necessary fulfilment of the creation of a Treaty-based relationship. Thus it states: ${ }^{125}$

... if the 1896 Urewera District Native Reserve Act was a faithful rendition of the parties' agreement, then that would mark the establishment of a genuine relationship based on the Treaty of Waitangi ...

Our conclusion would be different if the 1896 Act was so defective in reflecting the parties' recognition of each other's authority that it could not fairly be said to have brought the peoples of Te Urewera into a Treaty-based relationship with the Crown.

It goes on to state: ${ }^{126}$

... the Crown acted consistently with Treaty principles in 1894 to 1896. It placed its relationship with the peoples of Te Urewera on a genuine Treaty-based, and unique constitutional footing.

That this is the central reasoning running throughout the report in relation to the constitutional claim (the claim that non-signatories are not bound by the Treaty) is evidenced by the commentary in an earlier chapter of the Report dealing with Te Whitu Tekau and the 1871 peace agreement between Tūhoe and Donald McLean (representing the Crown). In this chapter the Tribunal states: ${ }^{127}$

... the events of 1871 signaled the beginning of a new era for Tūhoe and the Crown, but fell short of establishing a reciprocal Treaty-based relationship. The April hui, at which Tūhoe accepted kawanatanga and sought a relationship with the Crown, and the November-December agreement, in which the Crown recognised the authority of Tūhoe chiefs to manage their own affairs and withdrew its forces from their rohe, were positive steps. But as it transpired, neither development was formalised and entrenched by the Crown.

The difficulty with this logic is that it is not apparent why the actions of the Crown, in acting consistently with its unilateral obligations under the Treaty (to act in good faith throughout the negotiations, to follow through on its side of the bargain, and then to formalise the agreement in question), should then create binding obligations on Tūhoe under an entirely separate agreement to

125 Waitangi Tribunal Te Urewera Pre-Publication Part II, above n 2, at 475.

126 Ibid at 485 .

127 Ibid at 355 (emphasis added). 
the one negotiated. The necessary consent on Tūhoe's part still appears to be lacking. This criticism is not a mere quibble given that the placing of Treaty obligations on Tūhoe is a heavy burden. The Tribunal itself acknowledged this when it likened the Treaty relationship to a marriage but stated, "... there is no equivalent to divorce from the Treaty relationship. Once that relationship is established it endures to guide both parties' behaviour". ${ }^{128}$

Furthermore, although a theoretical point which may have little practical impact, the Tribunal's insistence on assessing the Urewera Agreement "in Treaty terms"129 effectively denies that binding obligations could arise from the Urewera Agreement in and of itself. Instead, the Tribunal's approach implies that in order to hold the Crown accountable, an external litmus test (that of the Treaty) was necessary. But would it not be more logical to argue that the Urewera Agreement, given it was evidently of "constitutional significance", ${ }^{130}$ should be adhered to regardless of whether Treaty obligations exist or not? In this particular case, Te Urewera iwi negotiated in depth with the Crown over two years and it is acknowledged that both parties considered themselves bound by the Urewera Agreement. Why should the Urewera Agreement only create constitutional obligations on the Crown by virtue of an entirely separate document that Tūhoe had no input into and had not been a party to?

If the Urewera Agreement is to be upheld either way, this point may have little practical impact. However, viewed from a position of historical integrity, and given that the Tribunal contributes to the national historical narrative, ${ }^{131}$ the creation of such legal fictions is problematic. For example, it is possible to argue that the Urewera Agreement was a separate treaty, which would surely have been considered just as solemn to the iwi of Te Urewera, as the Treaty of Waitangi would have to the iwi who signed that; why should one be deemed a treaty sufficient to create binding obligations and the other not? Such historical inaccuracies are bound to have repercussions. As O'Malley notes, an overemphasis on the Treaty tends "to downplay the piecemeal extension of Crown control over hitherto Maori-governed districts", which raises questions of historical integrity when recognition of other agreements "as a form of treaty or compact reflects more accurately the situation on the ground". ${ }^{132}$ Furthermore, while in this situation the Tribunal managed to fabricate a legal fiction by which the Urewera Agreement could be considered, this may not always be the case; therefore the issue of whether the Tribunal can consider breaches of constitutionally significant agreements beyond the Treaty of Waitangi needs to be squarely addressed.

128 Ibid at 475 .

129 Ibid at 468.

130 Ibid at 482 .

131 See Giselle Byrnes The Waitangi Tribunal and New Zealand History, above n 75.

132 Vincent O'Malley "Treaty-Making in Early Colonial New Zealand", above n 79, at 151. 
Having established the problems in the Tribunal's approach, this article turns to consider how the Tribunal could have better approached the issue, to posit why it was that the Tribunal chose not to approach it in this way, and whether its reasons were well-founded.

\section{A BETTER APPROACH - DEBUNKING THE PERCEIVED OBSTACLES}

The obvious approach is both simpler and less convoluted than that which the Tribunal adopted. It would simply be to say that the Urewera Agreement defines the reciprocal relationship between the Crown and Tūhoe, rather than the Treaty of Waitangi. This should be the case even while the Crown may also owe unilateral obligations to Tūhoe under the Treaty. Why was this approach not followed? This article presents three possible reasons: first, it was an oversight in the Tribunal's reasoning; second it was because of the perceived difficulty presented by the Tribunal's statutory jurisdiction; or third it was because of the perceived political barriers to acknowledging constitutional Crown-Māori agreements beyond the Treaty. It will be argued however, that none of these reasons are insurmountable and that, in fact, the last two are over-stated, if not imaginary, difficulties.

\section{A Oversight in the Reasoning}

The Tribunal's approach probably partially stems from their failure to acknowledge as interlinked, the fact that Te Urewera iwi did not sign the Treaty of Waitangi, but that they did negotiate and consent to the Urewera Agreement. Tühoe's status as a non-signatory to the Treaty was dealt with directly in ch three of the report, ${ }^{133}$ yet barely mentioned at all in the chapter dealing with the UDNRA and its negotiation. Instead the Tribunal appeared to take the approach that the Treaty relationship was waiting in a state of suspension until Tūhoe took some action which the Tribunal could regard as sufficient to constitute an acceptance of the Treaty relationship. In reality however, it could be argued that, through recourse to a different agreement altogether, in effect Tūhoe rejected the Treaty. If the subsequent relationship merely symbolised the beginning of a Treaty relationship, then why was a separate agreement negotiated? Why were protracted negotiations necessary? Could Tūhoe not have signed a replica of the Treaty itself? Evidently there was something different about the Urewera Agreement, thus the fact that one was entered into and the other not must be an interrelated inquiry.

It is possible that the failure to link these points was somewhat of a strategic side-step on the Tribunal's part in order to avoid asking larger questions relating to the cession of sovereignty by iwi who did not sign the Treaty of Waitangi. While the Central North Island inquiry skirted this issue, they did state that the "Urewera Tribunal will have to consider the issue of cession in depth" and that they were "satisfied to leave it to the Urewera Tribunal for full determination". ${ }^{134}$ Despite this, what

133 Waitangi Tribunal Te Urewera Pre-Publication Part II, above n 2, at 125.

134 Waitangi Tribunal Report on Central North Island Claims (Wai 1200, 2008) at 196. 
the Urewera Tribunal in fact did was ignore the reality that they were dealing with non-signatory claimants, precisely as a result of its artificial finding that through the Urewera Agreement Tūhoe entered a Treaty of Waitangi relationship with the Crown. In effect this finding retrospectively turned Te Urewera iwi into signatories, at least conceptually, and thereby reduced the issue of cession in relation to non-signatories into an irrelevant non-issue. Ultimately this reasoning obscured the crucial point that Tūhoe never signed the Treaty of Waitangi.

\section{B A Matter of Jurisdiction}

In all likelihood the Tribunal was probably only doing its best to incorporate the Urewera Agreement within the confines of its statutory jurisdiction and was therefore at pains to emphasise that the Urewera Agreement was to be assessed "in Treaty terms". ${ }^{135}$ Undoubtedly the Tribunal is stuck between a rock and a hard place in cases like this when it is faced with an agreement that it acknowledges has clear constitutional significance, yet its jurisdiction limits it to assessing breaches of the Treaty of Waitangi. Consequently, an incentive is created for the Tribunal to create legal and historical fictions that allow it to fit New Zealand's legal history into a narrative defined by the Treaty of Waitangi. This allows it to ensure the best chance of redress for the claimants in situations of blatant injustice, or where matters of historical significance clearly should be acknowledged, such as the circumstances regarding the Urewera Agreement. This adds support to the claim that in the Waitangi Tribunal forum "the union between law and history is a marriage of convenience", 136 in which Tribunal history can be seen as "juridical history", "a mode of representing the past so as to make it available to legal and quasi-legal judgment in the present". ${ }^{137}$

This is most probably a flaw in the empowering legislation, which in turn is a product of the discourse of Treaty hegemony. It is highly doubtful whether the legislators consciously chose to exclude consideration of other agreements. In all probability this was an innocent oversight resulting from the dominance of uni-textual thought in the constitutional discourse and in the understandings of Crown-Māori relationships. While the Tribunal's approach is therefore ingenious, it serves only to perpetuate this myopic and reductionist view of New Zealand's legal history; legal history would undoubtedly benefit from a more accurate approach that is bold enough to acknowledge our constitutional landscape's multi-textual nature.

Despite all this, it does not even seem that the Tribunal's statutory jurisdiction is actually a valid obstacle in this case. Arguably it remains possible for the Tribunal to both act within its statutory

135 Waitangi Tribunal Te Urewera Pre-Publication Part II, above n 2, at 468.

136 Giselle Byrnes The Waitangi Tribunal and New Zealand History, above n 75, at 64.

137 Andrew Sharp "History and Sovereignty: A Case of Juridical History in New Zealand/Aotearoa" in Michael Peters (ed) Cultural politics and the university in Aotearoa/New Zealand (Dunmore Press, Palmerston North, 1997) 158 at 160 cited in Giselle Byrnes The Waitangi Tribunal and New Zealand History, above n 75 , at 17 . 
jurisdiction and find that the Urewera Agreement forms the basis for the reciprocal constitutional relationship between the Crown and Tūhoe. This is based upon the Tribunal's own reasoning, in this report and in others, that the Crown owes obligations to all Māori under the Treaty of Waitangi, regardless of whether the iwi in question signed the Treaty. ${ }^{138}$ Thus, in this case, the Crown owed unilateral obligations to Tūhoe from 1840. ${ }^{139}$ Bearing this in mind one could apply Boast's general suggestion as to how particular agreements between the Crown and specific iwi may be recognised. Boast posits that: ${ }^{140}$

The way forward lies in the suggestion ... that the Treaty of Waitangi does not preclude later agreements being made with particular groups, and that the various principles of the Treaty that have been developed by the Tribunal embody the concept that later, particular pacts ought to be kept.

In other words, Treaty principles do not permit the Crown to break promises, duly negotiated, with iwi. Indeed this very approach was adopted by the Tribunal in 2008 in the Central North Island Claims report when, in dealing with the Fenton Agreement (one of the three regional pre-emptive agreements of which the Urewera Agreement is one), it argued that "the Crown should reasonably have been expected to keep the promises and engagements that it made with Maori", even if these are "over and above the Treaty engagements". ${ }^{141}$ Under the Treaty of Waitangi, "[t]he Crown must be held accountable for the performance (or non-performance) of its promises and obligations". ${ }^{142}$

Thus the Crown is bound to act consistently with the Urewera Agreement because it is required to do so through its obligations to Tūhoe under the Treaty of Waitangi. However this does not bring Tūhoe into a Treaty relationship because these obligations are unilateral. For their part Tūhoe is of course bound by the terms conceded in the Urewera Agreement. Consequently the reciprocal relationship between the Crown and Tūhoe is based on the Urewera Agreement, not the Treaty. As argued, this can be justified while still operating within the Tribunal's statutory jurisdiction.

\section{Political Problems with Acknowledging such Agreements}

The Tribunal's approach may also be symptomatic of a more general reluctance towards embarking upon consideration of the significance of other supposed treaties and agreements between the Crown and Māori. Apart from a fear that it could "unnecessarily confuse things", ${ }^{143}$

138 Waitangi Tribunal Te Urewera Pre-Publication Part I, above n 1, at 152; Waitangi Tribunal Te Urewera Pre-Publication Part II, above n 2, at 466; Waitangi Tribunal Report on Central North Island Claims, above n 134, at 196 and 206.

139 Waitangi Tribunal Te Urewera Pre-Publication Part I, ibid at 132 and 152.

140 Richard Boast "Recognising Multi-textualism: Rethinking New Zealand's Legal History", above n 2, at 575.

141 Waitangi Tribunal Report on Central North Island Claims, above n 134, at 180.

142 Ibid at 181 .

143 Richard Boast "Recognising Multi-textualism: Rethinking New Zealand's Legal History", above n 2, at 582. 
there is certainly a question as to whether it is fair that some iwi should have different entitlements to others, simply for reasons of Crown inconsistency. In Te Urewera's case, it is possible to argue that in part the Crown made the particular concessions that it did for self-interested motives, including the practical desire to consolidate Crown control in the Ureweras. ${ }^{144}$ Should Tūhoe now be accorded greater rights because the Crown found it harder to exert force in Te Urewera in contrast to different areas and therefore adopted a "piecemeal" approach to extend its control? ${ }^{145}$ Arguably this situation could be considered even more problematic given that the Tribunal has established that the Crown still owes Tūhoe all the obligations it owes to all other iwi under the Treaty of Waitangi. ${ }^{146}$ Thus Tūhoe could gain rights, not only under the Treaty, but also under the Urewera Agreement, despite the fact its leaders never signed the Treaty. Clear potential exists for this to instigate a sense of injustice.

Indeed, the Tribunal in the past has highlighted such difficulties with recognising that the Crown owes "particular obligations to any one iwi". ${ }^{147}$ In the Kaipara report the Tribunal stated that even if a "special relationship" existed between the Crown and a specific iwi, this "should have no bearing on the Crown's Treaty responsibilities to that group". ${ }^{148}$ It also argued that if the opposite were found, this could mean that some iwi might gain greater or lesser benefits depending on whether they had historically been seen as loyal or rebels. ${ }^{149}$

This approach has been criticised by Boast, ${ }^{150}$ and it seems that since the Kaipara report the Tribunal has altered its position somewhat. Indeed, in the Te Urewera report, when considering the claimants' constitutional claim derived from their status as non-signatories of the Treaty, the Tribunal appeared to concede more of a context-specific approach, stating that "striking a practical balance between the Crown's authority and the authority of a particular iwi ... must be a matter for negotiation ... tailored to the circumstances". ${ }^{151}$

144 Danny Keenan "Autonomy as Fiction: The Urewera Native District Reserve Act 1896", above n 43, at 8082 and 91; Anita Miles Te Urewera, above n 6, at 502-503.

145 Vincent O'Malley "Treaty-Making in Early Colonial New Zealand", above n 79, at 151.

146 Waitangi Tribunal Te Urewera Pre-Publication Part I, above n 1, at 466 ; Waitangi Tribunal Report on Central North Island Claims, above n 134, at 196 and 206.

147 Richard Boast "Recognising Multi-textualism: Rethinking New Zealand's Legal History", above n 2, at 574 (emphasis in original)

148 Waitangi Tribunal Kaipara Report (Wai 674, 2006) at 159 cited in Richard Boast "Recognising Multitextualism: Rethinking New Zealand's Legal History", ibid at 574.

149 Ibid.

150 Ibid at $574-575$.

151 Waitangi Tribunal Te Urewera Pre-Publication Part I, above n 1, at 126. 
Relating this somewhat abstract discussion to its potential practical implications and the fairness or otherwise of such implications, one possible outcome of recognising the Urewera Agreement and the specific entitlements it offers, could be a form of self-government for Tūhoe in the present day. ${ }^{152}$ As Brookfield notes, creating "semi-autonomous Maori districts is generally not possible. Perhaps the only exception relates to the Urewera Country". ${ }^{153}$ While this would mean differing treatment on the basis of what is essentially now a matter of practicality, Brookfield posits that it would not necessarily be prohibitively unjust; while it may not be possible to implement everywhere this "ought not to be a reason for failing to do it where it can be done". ${ }^{154}$

Furthermore, the corollary of refusing to recognise the constitutional significance of agreements other than the Treaty on grounds of fairness is the creation of an injustice against those iwi who entered into alternative agreements which they considered binding. The utilitarian view of justice promoted by rigidly adhering to Treaty hegemony does not outweigh the injustice inflicted upon iwi such as Tūhoe who not only negotiated their own agreements with the Crown, but who also chose not to buy into the hegemonic Treaty discourse in the first place.

\section{CONCLUSION}

This article has argued that the Urewera Agreement and UDNRA should together be seen as the central agreement defining the reciprocal Crown-Tūhoe relationship, rather than the Treaty of Waitangi. This argument has been put forward by reference to the singularity of the Urewera Agreement within the New Zealand context, the recognition that it is of considerable constitutional significance, alongside a growing need to acknowledge New Zealand's constitutional landscape as multi-textual.

As Boast noted in evidence provided before the Waitangi Tribunal, how the Urwera Agreement is to be conceptualised constitutionally is "an absolutely crucial ... constitutional and legal issue that cannot go away". ${ }^{155}$ Indeed it is "an essential aspect of analysing the Crown's relations with the peoples of Te Urewera". ${ }^{156}$ In light of this the Tribunal's findings on this issue are disappointing, seemingly buying into a fixation on the Treaty of Waitangi, without adequate rationalisation for this in the report it has produced.

Due recognition must of course be given to the environment within which the Tribunal operates. As discussed above, this environment is forged by both its statutory jurisdiction, as well as the

152 FM Brookfield Waitangi and Indigenous Rights: Revolution, Law and Legitimation, above n 75, at 172.

153 Ibid.

154 Ibid.

155 Richard Boast The Crown and Te Urewera in the 20th Century: A Study of Government Policy, above n 45, at 41. 
broader Treaty hegemony that dominates popular, historical, legal and constitutional discourse in New Zealand. Both of these are obstacles to acknowledging agreements, other than the Treaty of Waitangi, as having constitutional significance to a level allowing them to be seen as the primary compact defining the Crown's relationship with a particular iwi.

As has been argued, these obstacles do not provide insurmountable obstacles in this case. By failing to flesh out the issues at a deeper level, the Tribunal's analysis of the Urewera Agreement and the UDNRA, particularly its constitutional status and its status alongside the Treaty of Waitangi, is both unsatisfactory and convoluted. The Tribunal's report does little to shift Treaty discourse beyond its unilateral fixation and consequently the historical narrative it has produced fails to accord with factual reality. Furthermore it does Te Urewera iwi a disservice by essentially sidelining the agreement into which their leaders had invested most energy and placed most faith. On a broader level, the failure to move past a uni-textual notion of New Zealand's constitutional make-up will continue to hinder attempts to adequately recognise agreements such as the Urewera Agreement. What was an opportunity to deepen our nation's legal, historical and constitutional discourse has instead reinforced the poverty of this discourse even further. 
